\title{
A3 Subscale Diffuser Test Article Design
}

\author{
G.P. Saunders ${ }^{1}$ \\ Jacobs Technology Group, Stennis Space Center, MS, 39529
}

This paper gives a detailed description of the design of the A3 Subscale Diffuser Test (SDT) Article Design. The subscale diffuser is a geometrically accurate scale model of the A3 altitude rocket facility. It was designed and built to support the SDT risk mitigation project located at the E3 facility at Stennis Space Center, MS (SSC) supporting the design and construction of the A3 facility at SSC. The subscale test article is outfitted with a large array of instrumentation to support the design verification of the $\mathrm{A3}$ facility. The mechanical design of the subscale diffuser and test instrumentation are described herein.

\section{Nomenclature}

$\begin{array}{ll}\text { SSC } & =\text { Stennis Space Center, MS } \\ S D T & =\text { Subscale Diffuser Test Project } \\ E 3 C 1 & =\text { Cell } 1 \text { at test facility E3 at SSC } \\ \text { LOX } & =\text { Liquid Oxygen } \\ G H & =\text { Gaseous Hydrogen } \\ G N & =\text { Gaseous Nitrogen } \\ J S S & =\mathrm{J} 2-\mathrm{X} \text { Rocket Engine Subscale Simulator } \\ A^{*} & =\text { Nozzle Throat Area } \\ A n e & =\text { Supersonic Nozzle Exit Area } \\ A d & =\text { Capture Duct Area }\end{array}$

\section{Introduction}

$\mathrm{T}$ HIS document provides a description of the design the A3 Subscale Diffuser Test (SDT) article. The subscale diffuser is a geometrically accurate scale model of the A3 altitude simulating rocket test facility currently under construction at Stennis Space Center, MS (SSC). The A3 test facility is being built to support man-rating of the J2$\mathrm{X}$ engine. The $\mathrm{J} 2-\mathrm{X}$ is to be the upper stage engine on the Constellation program's ARES I and ARES V vehicles. The SDT test project is located in Cell 1 of the E3 test facility (E3C1) at SSC. A general description of the SDT project can be found in Reference 1, while an overall description of the facility layout and operation can be found in Reference 2.

The purpose of the SDT project is to provide necessary design validation data to the A3 project, specifically to verify the aerodynamic performance of the exhaust train, which consist of a rocket diffuser, $1^{\text {st }}$ stage (or Y-stage) steam ejector and diffuser, and a $2^{\text {nd }}$ stage (or Z-stage) steam ejector and diffuser, and to obtain the design heat flux levels for the various elements of the exhaust train (rocket diffuser, $1^{\text {st }}$ stage ejector diffuser, elbow, $2^{\text {nd }}$ stage ejector diffuser, and sub-sonic exit diffuser).

Care was taken during the design of the subscale hardware to preserve an accurate aerodynamic and thermodynamic representation of the full scale facility. The selected scale was determined to be large enough to ensure data correlation yet small enough to be economically feasible and utilize existing rocket hardware and facility infrastructure located at SSC.

The SDT is outfitted with a large array of instrumentation to allow the aerodynamic and thermodynamic performance of the exhaust train to be measured. Measurements critical to the design of the A3 facility include: the operating pressure ratios of the $1^{\text {st }}$ and $2^{\text {nd }}$ stage ejectors and diffusers and the rocket diffuser, and measurement of the heat flux throughout the exhaust train. This paper will describe the instrumentation and data acquisition system used to obtain the critical test article measurements.

\footnotetext{
${ }^{1}$ A3 Subscale Test Project Manager, Building 3226, Stennis Space Center, MS, 39529, Senior Member. 


\section{Mechanical Design}

The first step in the mechanical design of the A3 Subscale Diffuser was to determine a suitable scale for testing. It was required that the scale be large enough to provide valid test data yet small enough to be economically feasible to build. It also had to accommodate the hardware selected for use as the J2-X Subscale Simulator (JSS) rocket. The JSS is a pressure fed LOX/GH fueled rocket that is geometrically similar to the J2-X from its throat to the nozzle exit plane (NEP) and is operated at the same oxidizer-to-fuel ratios and chamber pressures. Detailed information regarding JSS design and activation is contained in Reference 3.

The selected scale allowed the use of common pipe stock for the long $1^{\text {st }}$ and $2^{\text {nd }}$ stage ejector diffusers and the mitered diffuser elbow. The selected scale was considered large enough for accurate aerodynamic simulation largely because scale simulation of AEDC's J6 solid rocket test facility performed in the 1980s at a similar scale had proved accurate (Reference 4). It also allows the operation of the JSS at conditions that required little modification to the existing infrastructure of E3C1 at Stennis. An elevation of the A3 Subscale Diffuser is shown in Figure 1.

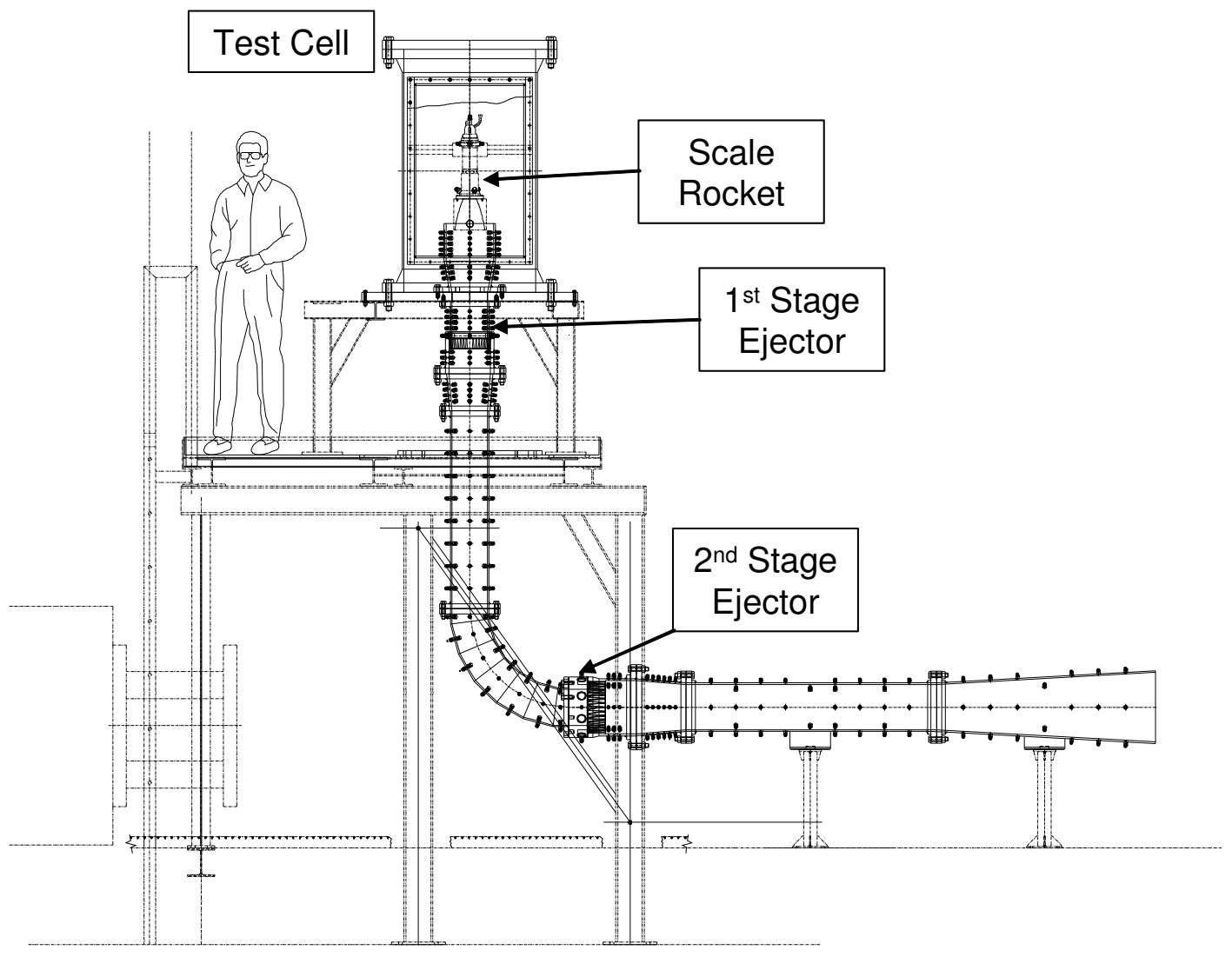

Figure 1. A3 Subscale Diffuser Elevation

\section{A. Test Cell}

The SDT test cell serves as the vacuum chamber for the simulation of altitude conditions. It is the only portion of the A3 Subscale Test Article that is not geometrically accurate. The A3 test cell is a large, plate fabricated, structure with a hemispherical head. It was deemed that accurate geometric scaling was not necessary because the test cell only serves as vacuum chamber and is not part of the aerodynamic flow path. Hence, only the test cell volume was scaled so that accurate scaling of the chamber evacuation rate was preserved. In addition, care was taken to ensure that the outside diameter of the JSS nozzle extension at the nozzle exit plane (NEP) and rocket diffuser inlet were accurately scaled to give the correct scale aperture area, and hence an evacuation time constant proportional to the model scale. This allowed the use of common stock for construction.

The top of the test cell is a blind flange while the floor of the test cell is a thick plate. The test cell floor has blind tapped holes for mounting the test cell via a slip-on flange at its base. The floor is mounted to facility structural steel. The floor also has blind tapped holes for the mounting of the rocket diffuser in the test cell and $1^{\text {st }}$ stage ejector assembly underneath (or outside) the test cell. The floor is bored to the inside diameter of the rocket 
diffuser throat, thus the floor creates the first section of the rocket diffuser throat. This point will be discussed in more detail later in this report.

A large door was provided with hinges to access the JSS, rocket diffuser, and instrumentation inside the test cell. A multitude of penetrations occupy the test cell wall to allow the entry of instrumentation, JSS propellant feed lines, and JSS cooling water supply and return plumbing. Wall penetrations are all male 37 degree flared tube bosses to allow direct connection of flared tubing. The test cell head has two penetrations that permit GN test cell purge gas to be admitted.

The test cell also houses the thrust takeout structure for the JSS engine and a GN purge diffuser ring. JSS thrust is transmitted through the test cell wall into the floor and then through the facility structure to ground. Instrumentation inside the test cell includes test cell pressure transducers, high response thermocouples to measure rocket diffuser surface temperatures, high response rocket diffuser pressure transducers, and a test cell camera and light source. Photos of the test cell are shown in Figures 2 and 3.

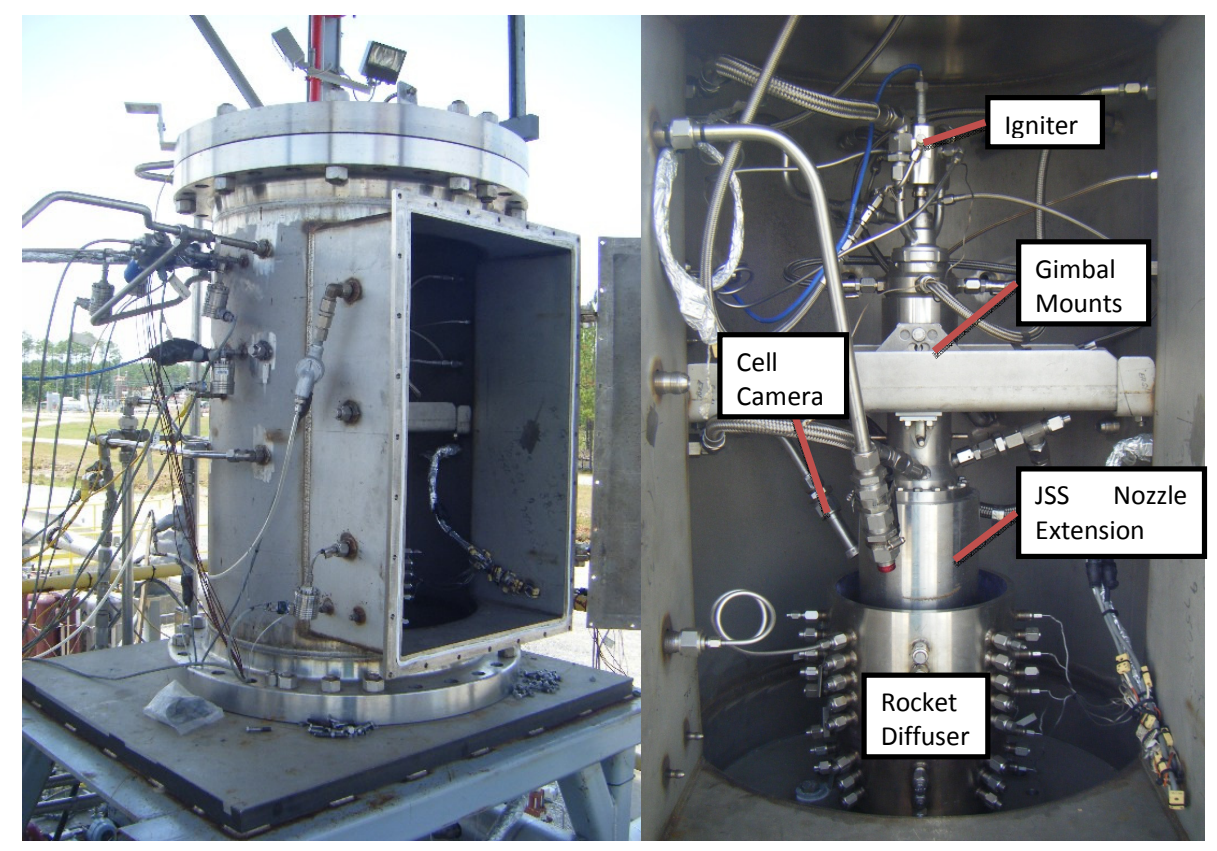

Figure 2. Test Cell Exterior (Left) and Test Cell Interior (Right)

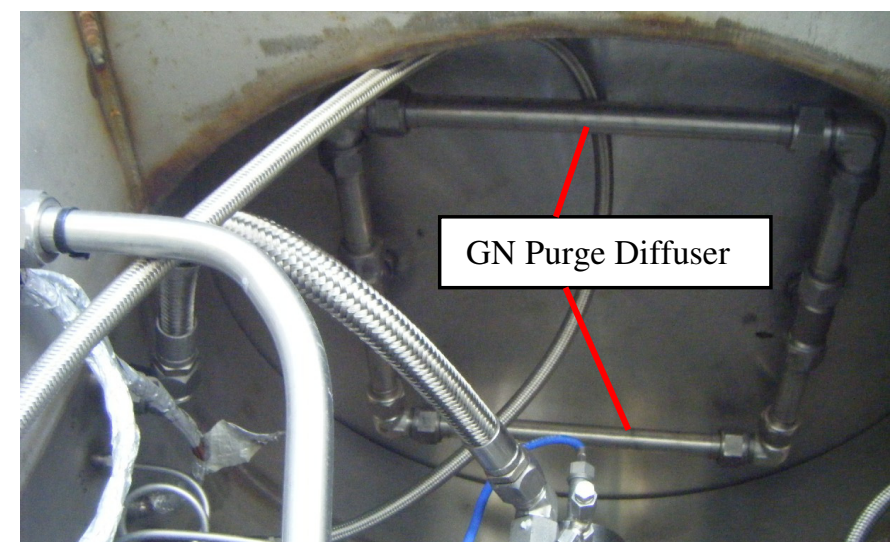

Figure 3. Test Cell GN Purge Diffuser Ring

\section{B. Rocket Diffuser}

The rocket diffuser is a second throat design consisting of a capture duct (to capture the rocket plume), a conical contraction, and a cylindrical "second throat". The capture duct and contraction are housed inside the test cell as 
shown in Figure 2. The exit of the contraction has a custom flange that allows bolting to the test cell floor. As stated previously, the test cell floor is bored to the inside diameter of the rocket diffuser throat creating the first section of the throat. The remainder of the rocket diffuser throat is bolted to the underside of the test cell floor and is part of the $1^{\text {st }}$ stage ejector assembly. The rocket diffuser throat has a relatively short $\mathrm{L} / \mathrm{d}$ to allow close coupling of the $1^{\text {st }}$ stage ejector to prevent backflow of steam and engine exhaust gases into the test cell during engine shutdown. The aft end of the rocket diffuser throat can be seen in Figure 4. Aerodynamic performance test results are outlined in Reference 5.

\section{C. $1^{\text {st }}$ Stage Ejector and Diffuser}

The $1^{\text {st }}$ stage ejector is an annular design with an array of supersonic nozzles around the outside circumference of the rocket diffuser throat. The annular ejector design avoids the complex cooling water system that would be required to protect the nozzle and support structure of a centerbody design. The $1^{\text {st }}$ stage ejector diffuser is a second throat design with a conical contraction. A photo of the $1^{\text {st }}$ stage ejector assembly and diffuser is shown in Figure 4 .

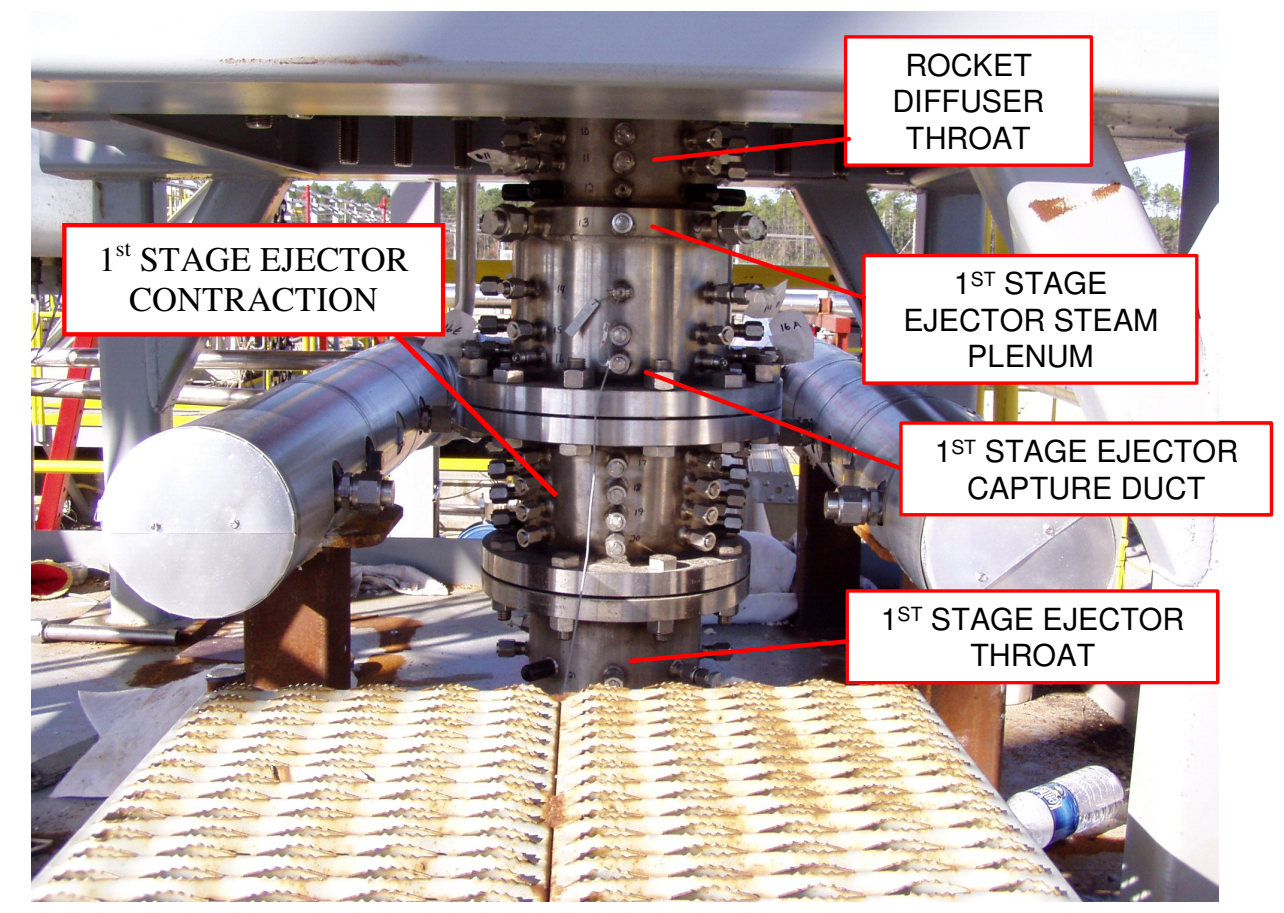

Figure 4. $1^{\text {st }}$ Stage Ejector Assembly and Diffuser

\section{1. $1^{\text {st }}$ Stage Ejector Assembly}

The $1^{\text {st }}$ stage ejector assembly is a weldment with flanges on either end to interface with the test cell floor on the upstream end and the $1^{\text {st }}$ stage diffuser contraction on the downstream end. The assembly consists of four major parts; the aft end of the rocket diffuser throat, the $1^{\text {st }}$ stage ejector steam plenum, the supersonic ejector nozzles, and the $1^{\text {st }}$ stage ejector capture duct. The rocket diffuser section is common pipe stock while the steam plenum, nozzle, and capture duct sections are machined parts. The steam plenum and capture duct section are cylindrical parts suitable for standard lathe and mill machining. The steam plenum also has four male 37 degree flare bosses to allow steam feed tubing to be installed.

The ejector nozzle section is a complicated part requiring electrical discharge machining (EDM) to create the nozzle geometry. The nozzle inlets were created using EDM sinker probes while the throats and supersonic nozzles were fabricated with an EDM wire. First stage ejector assembly details are shown in Figure 5. 


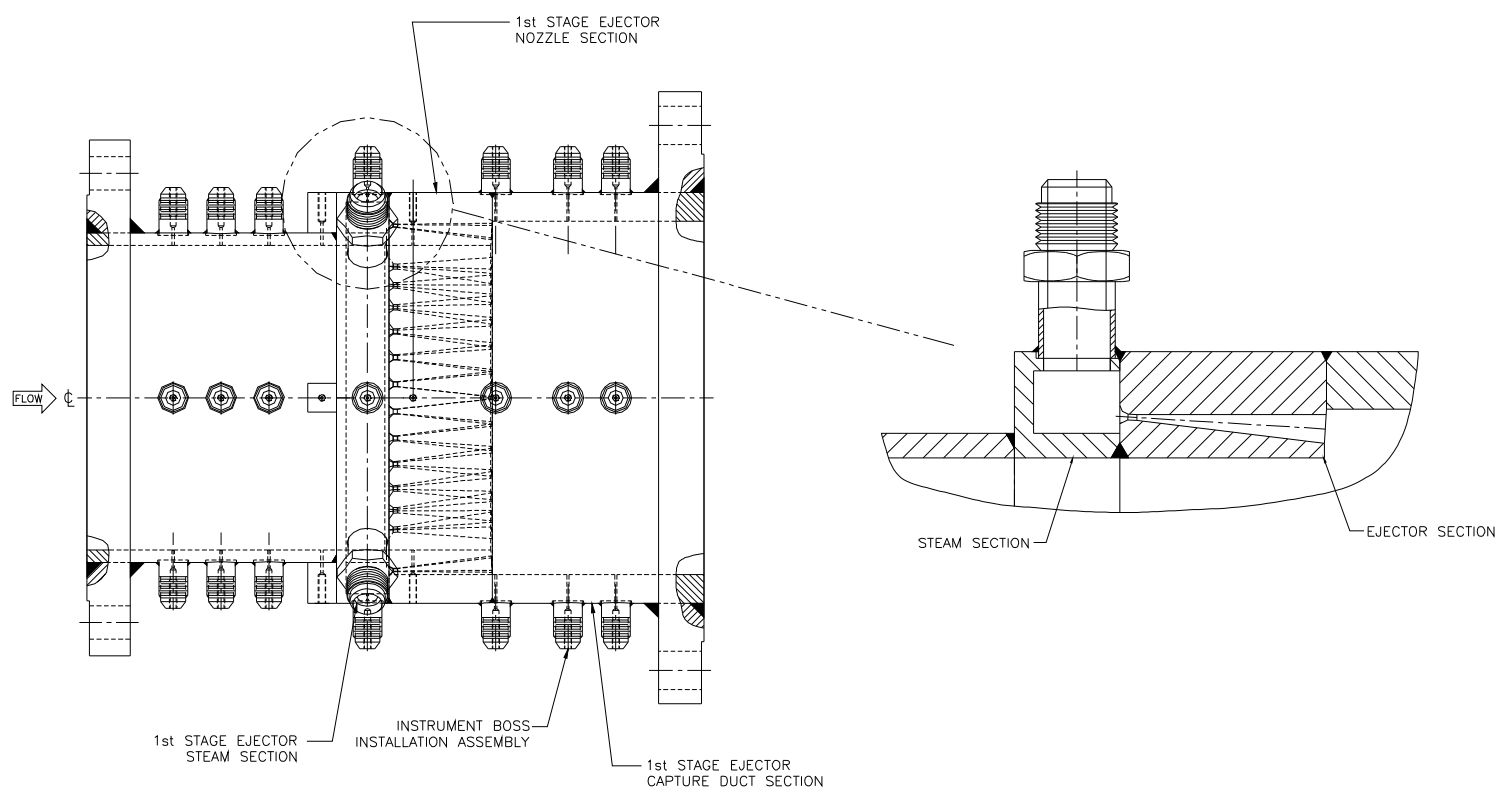

Figure 5. $1^{\text {st }}$ Stage Ejector Assembly

Two $1^{\text {st }}$ stage ejector assemblies have been designed and built, one with conical nozzles and one with trapezoidal nozzles. The conical nozzle version was the original design containing 38 nozzles. Testing showed that the ejector nozzle test cell pumping efficiency has a strong dependence on the capture duct to nozzle exit area ratio, Ad/Ane. The conical ejector design did not meet performance requirements. Hence, the $1^{\text {st }}$ stage ejector assembly was redesigned to incorporate trapezoidal nozzle with a much larger nozzle area ratio resulting in a smaller capture duct to nozzle exit ratio. The trapezoidal design contain 40 nozzles and Ane/A* was increased while $\mathrm{Ad} / \mathrm{A}^{*}$ was maintained. First stage ejector test results are discussed in Reference 6. Figure 6 shows both designs looking upstream.

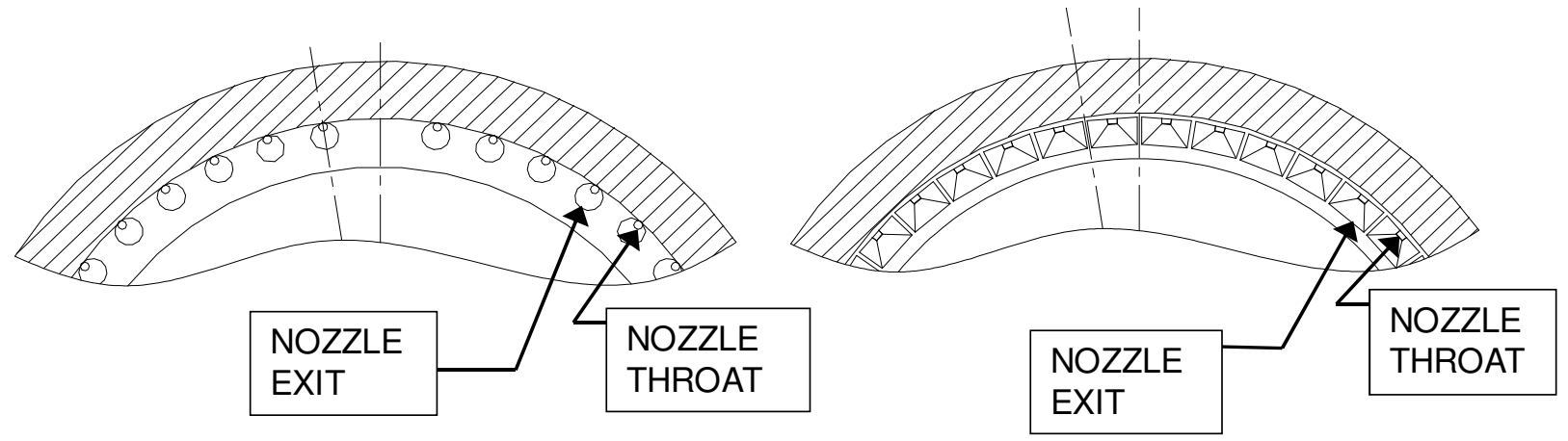

Figure 6. Section Looking Upstream into Ejector Nozzles; Conical Design (Left), Trapezoidal Design (Right)

\section{2. $I^{\text {st }}$ Stage Ejector Diffuser Contraction and Second Throat}

The contraction to the $1^{\text {st }}$ stage diffuser throat is a simple machined cone with flanged interfaces to the $1^{\text {st }}$ stage ejector assembly and $1^{\text {st }}$ stage diffuser throat on the upstream and downstream end, respectively. The contraction can be seen in the photo in Figure 4 above. The $1^{\text {st }}$ stage diffuser throat is fabricated from common pipe stock with flanges on each end. The upstream end is bolted to the contraction while the downstream end is bolted to the diffuser elbow. The $1^{\text {st }}$ stage ejector throat has an $\mathrm{L} / \mathrm{d}$ sized to maximum diffuser pressure recovery. The last row of instrumentation ports on the $1^{\text {st }}$ stage diffuser throat have been modified since initial installation to allow water to be injected after rocket firing to cool the downstream elbow.

American Institute of Aeronautics and Astronautics 092407 


\section{Diffuser Elbow}

The diffuser elbow is constructed of pipe stock. Straight pipe was cut and welded together to form a scale mitered elbow. The elbow is a seven segment miter with a large elbow radius to diameter ratio, $r / d$. An upstream flange connects the elbow to the $1^{\text {st }}$ stage ejector diffuser throat. A downstream flange mates to the suction side of the $2^{\text {nd }}$ stage diffuser. The diffuser elbow is shown in Figure 7 along with its instrumentation port row identification numbering.

\section{E. $2^{\text {nd }}$ Stage Ejector and Diffuser}

The $2^{\text {nd }}$ stage ejector is an annular design with an array of supersonic nozzles around the outside circumference of the suction duct just downstream of the diffuser elbow. The $2^{\text {nd }}$ stage ejector diffuser is a second throat design with a conical contraction. The $2^{\text {nd }}$ stage ejector is very similar in design and size to the annular steam ejector installed

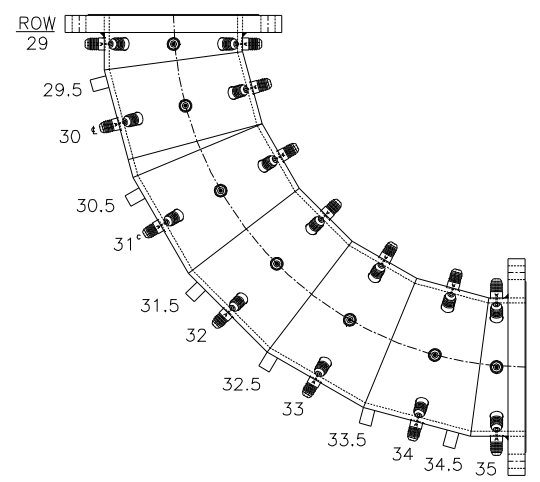

Figure 7. Diffuser Elbow the J6 facility at Arnold Engineering Development Center (AEDC). The original $2^{\text {nd }}$ stage diffuser design included a conical subsonic exit diffuser. Photos of the $2^{\text {nd }}$ stage ejector assembly and diffuser are shown in Figure 8.

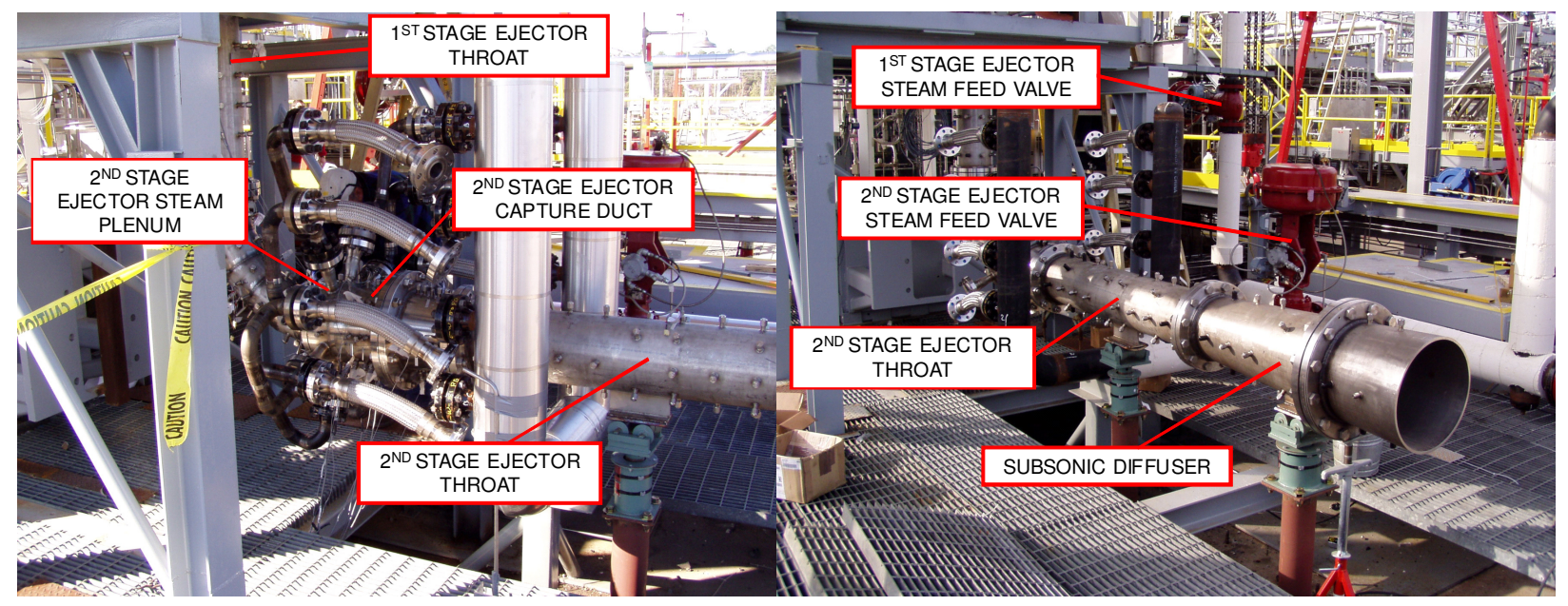

Figure 8. Views of the $2^{\text {nd }}$ Stage Ejector and Diffuser

\section{1. $2^{\text {nd }}$ Stage Ejector Assembly}

The $2^{\text {nd }}$ stage ejector assembly is constructed similar to the $1^{\text {st }}$ stage ejector assembly. The flanges on the assembly interface with the diffuser elbow on the upstream end and the $2^{\text {nd }}$ stage diffuser contraction on the downstream end. The assembly consists of three major parts; the $2^{\text {nd }}$ stage ejector steam plenum, the supersonic ejector nozzles, and the $2^{\text {nd }}$ stage ejector capture duct. Unlike the $1^{\text {st }}$ stage ejector, the larger $2^{\text {nd }}$ stage ejector plenum and the closer proximity of the ejector to upstream hardware required that the flange connection to the diffuser elbow be integral to the $2^{\text {nd }}$ stage ejector plenum. The upstream face of the assembly has a raised face flange surface with blind tapped holes to accept bolts for attaching the assembly to the diffuser elbow. The steam plenum and capture duct section are cylindrical parts suitable for standard lathe and mill machining. The $2^{\text {nd }}$ stage steam plenum also has eight pipe flange nozzles to allow steam feed piping to be installed. Note that the $2^{\text {nd }}$ stage ejector steam flow is an order of magnitude larger than the $1^{\text {st }}$ stage ejector steam flow.

Like the $1^{\text {st }}$ stage ejector, electrical discharge machining (EDM) was used to create the nozzle geometry. The nozzle inlets were created using EDM sinker probes while the throats and supersonic nozzles were fabricated with an EDM wire. The $2^{\text {nd }}$ stage ejector contains 36 trapezoidal nozzles. The capture duct to nozzle throat area ratio. $2^{\text {nd }}$ stage ejector test results are detailed in Reference 6. Second stage ejector assembly details are shown in Figure 9. 

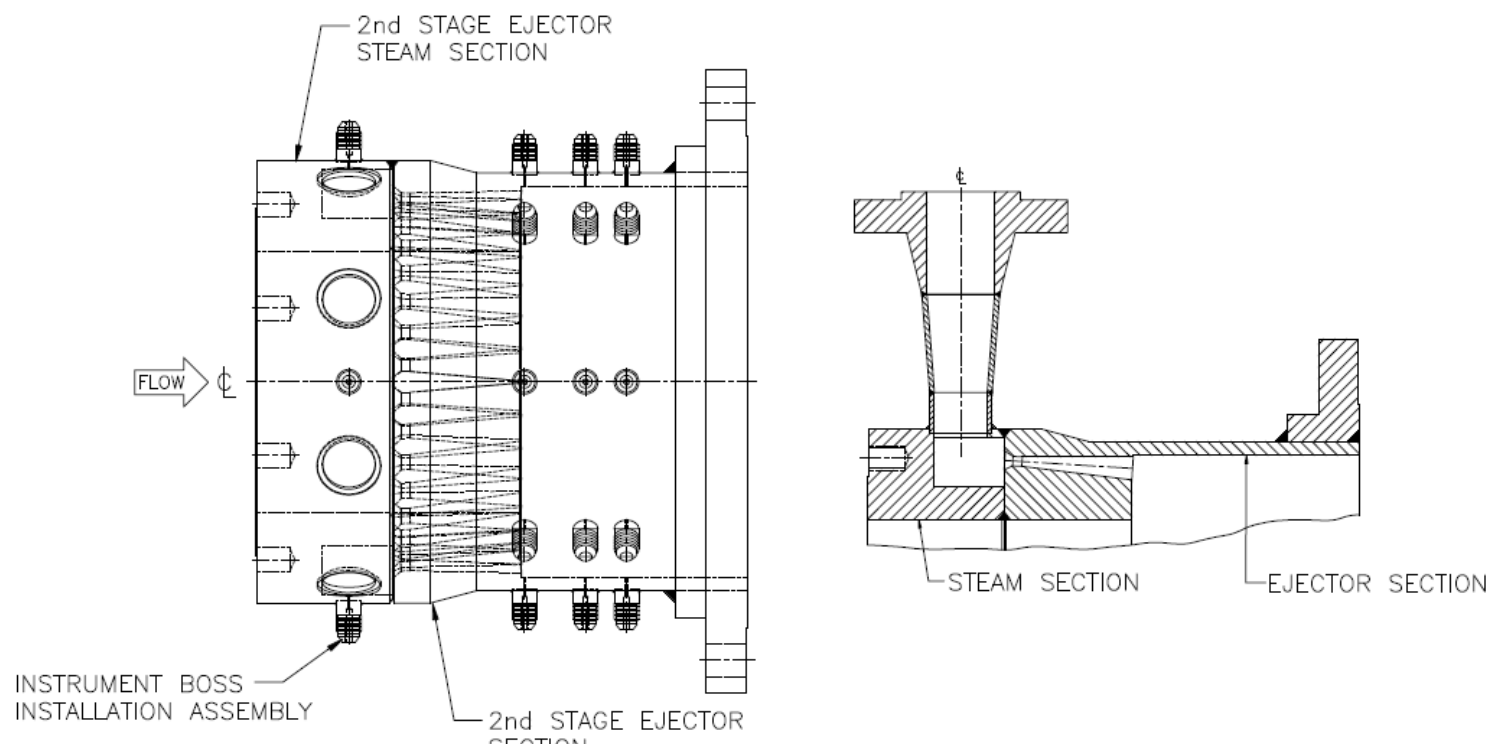

Figure 9. $2^{\text {nd }}$ Stage Ejector Assembly

\section{2. $2^{\text {nd }}$ Stage Ejector Diffuser Contraction, Second Throat, and Subsonic Diffuser}

The contraction to the $2^{\text {nd }}$ stage diffuser throat is a simple machined cone with flanged interfaces to the $2^{\text {nd }}$ stage ejector assembly and $2^{\text {nd }}$ stage diffuser throat on the upstream and downstream ends respectively. The $2^{\text {nd }}$ stage diffuser throat is fabricated from common pipe stock with flanges on each end. The upstream end is bolted to the contraction while the downstream end is bolted to the diffuser elbow. The length of the $2^{\text {nd }}$ stage ejector throat was increased when it was determined that the subsonic diffuser was not needed.

The subsonic diffuser was designed to give operating pressure ratio margin when the ejector-diffuser system was operating with steam flow only (rocket off). It was determined through testing that the subsonic diffuser allowed about $10 \%$ extra operating pressure ratio in the $2^{\text {nd }}$ stage ejector. While operating as designed, tests with the subsonic diffuser removed showed that sufficient margin existed without the presence of the subsonic diffuser. Also, the subsonic diffuser had supersonic inlet flow thus allowing flow separation to occur in the diffuser. The separated flow caused transitory loads to be transmitted throughout the structure. The subsonic diffuser was subsequently removed and a short section of pipe was added to the diffuser throat to increase the L/d. Details of these tests are covered in Reference 6. The diffuser throat and subsonic diffuser are shown in the Figure 8 photographs.

\section{F. Instrumentation Ports}

Early in the design process it was decided to build a three-in-one instrumentation boss to allow the use of high response pressure transducers, high response thermocouples, or allow the connection of pneumatic tubing for static pressure measurements. This was done mainly because, during design, it was unclear where the various measurements would ultimately be required. Therefore it was decided to install as many instrument ports as possible and use the three-in-one boss at each port to allow test objectives to dictate where measurements were needed on a test-by-test basis. The boss design contains a thru hole to allow the insertion of a high response coaxial thermocouple or to serve as diffuser wall pressure port. The upper portion of boss has a tapped hole for installation of the high response thermocouples or installation of high response pressure transducers. The outside of the boss is standard male 37 degree flare boss to allow tubing to be directly connected at any boss. A cross section of the boss design and a photo of bosses with and without a high response pressure transducer installed are shown in Figure 10. Figure 11 details nomenclature used to number the multitude of instrumentation bosses installed on the diffuser. 


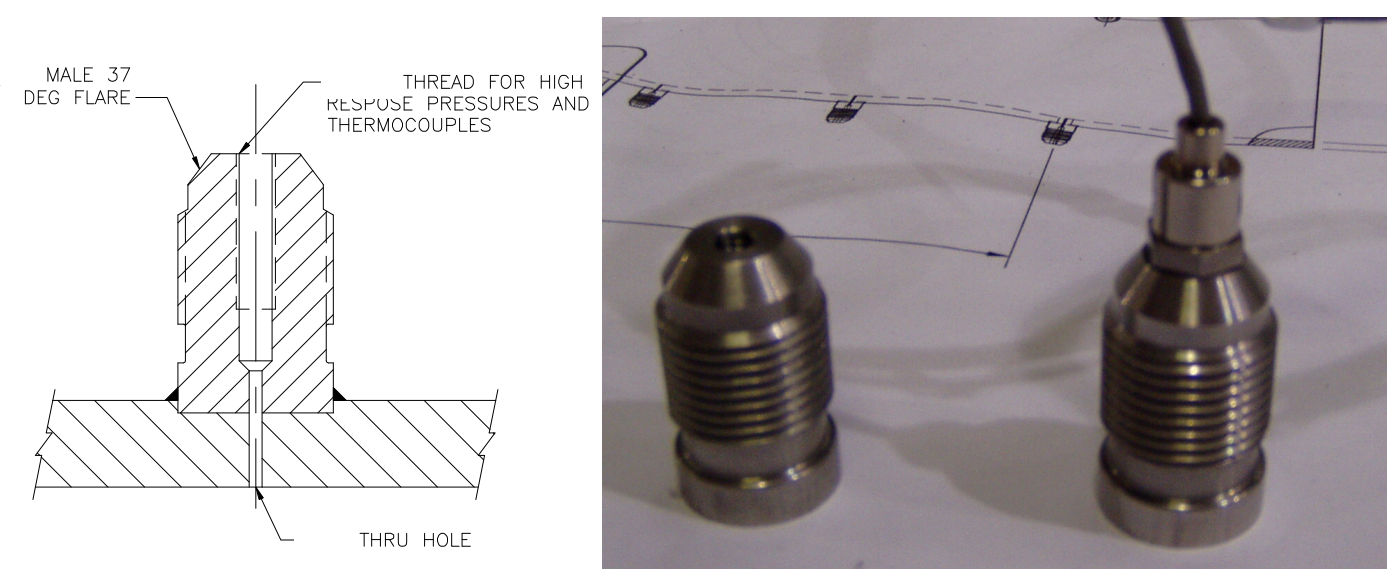

Figure 10. Instrumentation Boss Cross Section and Photos

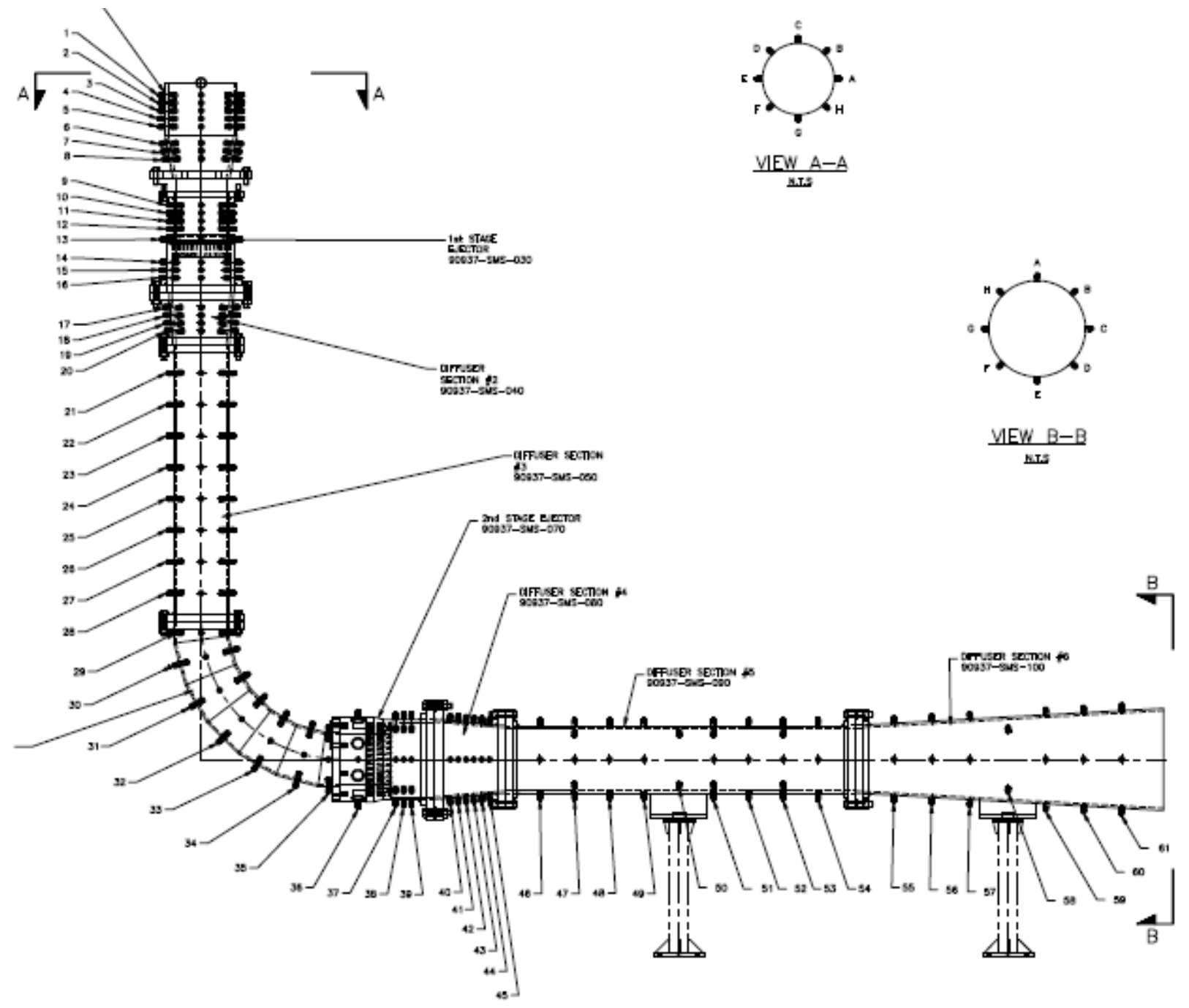

Figure 11. Instrumentation Port Nomenclature Diagram 


\section{Instrumentation}

Three separate data systems are used to obtain data for the SDT project. The SSC E3 facility low speed data acquisition system $(250 \mathrm{~Hz})$ is used to obtain primary facility data such as steam generator and JSS feed pressures, temperatures, flow rates, etc. A stand alone 48 channel high speed data acquisition system on loan from AEDC is used to obtain high response pressure and temperature data from the A3 subscale diffuser at $10 \mathrm{kHz}$. Lastly, two 16 channel high accuracy Scanivalve transducer "bricks" are used to obtain steady state static pressure distributions along the diffuser exhaust train. All SSC facility (low speed) and Scanivalve data are sent to the high speed system via Ethernet and are time synced into a single data file.

\section{A. High Response Pressure Transducers}

Piezoresistive pressure transducers are used for the high response absolute pressure measurements in the exhaust train. The transducers employed silicon strain gauges bonded to a machined silicon diaphragm. The transducers have a manufacturer's quoted accuracy of $0.5 \%$ of full scale output and maximum temperature limit of 500 deg F. The transducers are threaded and are directly screwed into the instrument bosses described above.

\section{B. High Accuracy Pressure Transducers (Low Speed)}

Two, 16 channel transducer modules, or "bricks", are used to obtain low response static pressure measurements along the length and circumference of the exhaust diffuser ducting. The units are stand alone analog-to-digital devices requiring only power and communication via Ethernet connection. Each module contains 16 individual temperature compensated piezoresistive pressure sensors with a quoted accuracy of $0.05 \%$ of full scale output. The bricks are housed in gaseous nitrogen purged enclosures. Tubing is routed from each individual transducer to the instrument boss location of choice. The enclosures are located as near as possible to the test article to maximize the response of the transducer measurements. A high accuracy pressure transducer module installation is shown in Figure 12 .

\section{High Response Co-Axial Thermocouples}

Type K, high response coaxial surface mount thermocouple probes are used to obtain high response internal diffuser wall temperatures for the purpose of calculating diffuser heat flux rates. The coaxial thermocouples consist of a small wire of Alumel coated with a 0.0005 inches thick ceramic insulator of high dielectric strength swaged in a tube of Chromel P. The thermocouples have a recommended temperature range of -450 to 2500 deg $\mathrm{F}$. The thermocouple junction is obtained by installing the thermocouple slightly protruding through the pipe wall then fairing the probe back flush with the wall surface with a soft grinding stone. A so called sliver junction is created by the grinding process yielding a response time on the order of 100 micro-seconds $(10 \mathrm{kHz})$.

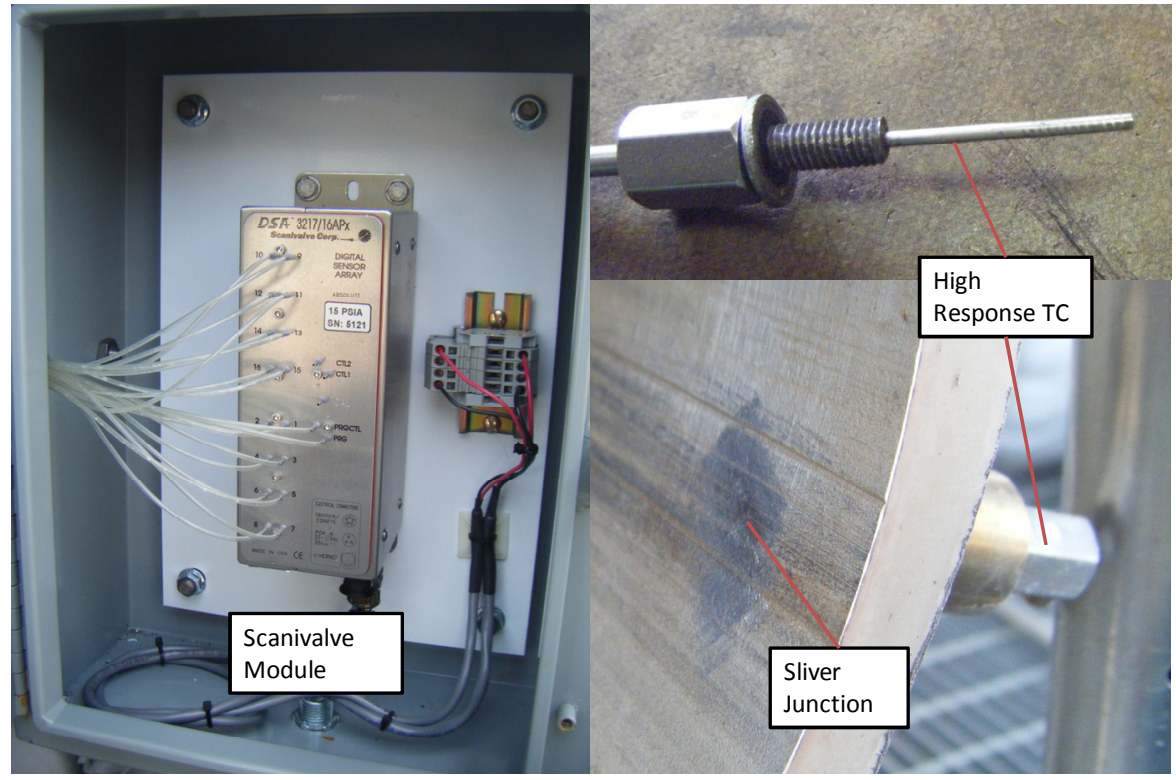

Figure 12. Scanivalve "brick" (left) and High Response Coaxial Thermocouple (right) 


\section{Conclusions}

A general description has been given of the design of the A3 Subscale Diffuser test article. It is a modular design and has proved to be very robust. To date, over 200 steam generation tests have been conducted with steam flow through the $1^{\text {st }}$ and $2^{\text {nd }}$ stage ejectors and over $100 \mathrm{~J} 2-\mathrm{X}$ subscale simulator (JSS) rocket firings have been conducted with all of the original diffuser hardware. The multitude of multi-function instrumentation bosses has also proven to be invaluable as temperature and pressure instrumentation have been moved on a regular basis depending on the current test objectives. Some bosses have even been modified to inject diffuser elbow cooling water. In summary, the subscale diffuser has been a flexible, reliable, and invaluable test bed.

\section{References}

${ }^{1}$ Ryan, J., Mulkey, C.A., Raines, N.G., and Saunders, G.P., “An Overview of the A3 Subscale Diffuser Test Project”, AIAA2008-4365, 2008.

${ }^{2}$ Saunders, G.P., Varner, D.G., and Grover, J.B., "Description and Operation of the A3 Subscale Facility", AIAA-2009-5097, 2009.

${ }^{3}$ Saunders, G.P., Raines, N.G., and Varner, D.G., "Design, Activation, and Operation of the J2-X Subscale Simulator (JSS)", AIAA-2009-5098, 2009.

${ }^{4}$ Beavers, D.R., "Large Rocket Test Facility J-6 Activation/Validation", AEDC-TR-95-30, November 1995.

${ }^{5}$ Saunders, G.P., and Yen, J., “A3 Subscale Rocket Hot Fire Testing”, AIAA-2009-5099, 2009.

${ }^{6}$ Saunders, G.P., and Wagner, D.A., “A3 Subscale Steam Ejector Performance Testing”, AIAA-2009-5100, 2009. 